\title{
Resource Use by Non-Native Ring-Necked Parakeets (Psittacula krameri) and Native Starlings (Sturnus vulgaris) in Central Europe
}

\author{
Christina Czajka, Michael P. Braun ${ }^{*}$ and Michael Wink ${ }^{*}$
}

\author{
Heidelberg University, Institute of Pharmacy and Molecular Biotechnology, Department of Biology, Im Neuenheimer \\ Feld 364, D-69120 Heidelberg, Germany
}

\begin{abstract}
In general, non-native bird species may competitively exclude native species from nest sites. The potential resource conflict between a native and an introduced bird species, the native European Starling (Sturnus vulgaris) and the introduced Asian Ring-necked Parakeet (Psittacula krameri), was inferred from hole occupancy in parks of the German Upper Rhine Valley (Wiesbaden, Mannheim, Schwetzingen, Edingen-Neckarhausen), where Ring-necked Parakeets have been known to occur for 15 to 35 years. Only $2.2 \%$ of trees $(\mathrm{n}=3487)$ had cavities with an entrance diameter $\geq 4 \mathrm{~cm}$. The number of unoccupied tree holes was high, representing $71 \%$ of 639 recorded cavities. A niche separation corresponding to tree size and tree species preferred by both bird species could be detected. Starling preferred trees with a diameter of $0.75 \pm 0.30 \mathrm{~m}$, whereas Ring-necked Parakeet favoured ones with $1.16 \pm 0.36 \mathrm{~m}$ in diameter. Both bird species were the most abundant hole-nesters in the examined cavities. Ring-necked Parakeets preferred Platanus $\mathrm{x}$ hispanica, which hosted $57 \%$ of all broods for the parakeet, but did not use Acer pseudoplatanus. Starling favoured Quercus robur with $25 \%$ of all broods, followed by A. pseudoplatanus with $19 \%$. P. x hispanica showed the highest numbers of cavities with 227 in total and a median of 3 holes per tree, partially produced by Ring-necked Parakeet. The largest colony-in-one-tree in this study was 9 for $P$. krameri and 5 for $S$. vulgaris. In this study, Starlings took over two nests from Ring-necked Parakeets, with one case vice versa, and Honeybees took over one active Ring-necked Parakeet nest.
\end{abstract}

Keywords: Ecological niche, invasive, nest-site competition, non-native, tree hole availability, tree preference.

\section{INTRODUCTION}

Non-native and especially invasive organisms are generally regarded as a major threat to biodiversity [1-5]. Their impact is apparently not equal over all habitats and ecoregions. Isolated tropical and subtropical island ecosystems are especially vulnerable to any disturbance like the arrival of new species [6-9]. Out of 433 threatened or extinct bird species and subspecies $70 \%$ turned out to be island taxa [10]. However, findings at continental level are different. Central Europe has seen a high rate of species turnover since the last glacial period [11] and no native animal species was lost due to competition with an introduced non-native species so far [12]. Species extinction caused by competition is considered less likely than by predators or pathogens [1315].

Anthropogenic influenced habitats like cities, disturbed and fertile soils are commonly regarded as centres of bioinvasions [16-18]. This is also the case for the Ring-necked Parakeet (Psittacula krameri), native to Southern Asia and sub-Saharan Africa. This species became established in Europe during the late 1960s and 1970s, when escaped cage birds of Asian origin began to breed in cities. Since then, numbers have increased to a total of 29,000 birds in Europe with strongholds in large metropolitan areas of the UK, Belgium, the Netherlands, Western Germany, and France

*Address correspondence to these authors at the Heidelberg University, Institute of Pharmacy and Molecular Biotechnology, Department of Biology, Im Neuenheimer Feld 364, D-69120 Heidelberg, Germany; Tel: $0049 \quad(0) \quad 6221 \quad 544881$; Fax: 0049(0) 6221 544884; E-mails: psittaciden@yahoo.de; Wink@uni-hd.de
$[19,20]$. Propagule pressure, meaning the number of escapes, in this species should also be high in the small-billed African subspecies, which are heavily traded. Between 1986 and 2008, 150,000 Ring-necked Parakeets have been exportted from Senegal alone (CITES), but failed to establish populations in Europe so far. In Belgium, there is some evidence for competition between Ring-necked Parakeets and native Nuthatches (Sitta europaea) [21]. The Ringnecked Parakeet is listed as one of the ' 100 worst invasive species' in Europe and as a potential competitor to the European Starling [4].

Despite a substantial population decline since the 1980s, the European Starling (Sturnus vulgaris) still remains one of the most common breeding birds in Europe and is a strong competitor for other hole nesters [22, 23]. In Britain, breeding success and spreading of the Great spotted Woodpecker (Dendrocopos major) increased dramatically during the past 20 years, which is mainly attributed to the decline of the Starling [24, 25]. The European Starling has been introduced worldwide to Australia, South Africa, New Zealand, and with greatest success to North America reaching from Alaska in the north as far south as Mexico, Cuba, and the Bahamas [20]. The impact of the Starling on the North American breeding birds is considered moderate as only for sapsuckers (Sphyrapicus spp.) a decline was potentially attributable to the Starling [26].

In 2008 , the number of potential breeding trees, bearing both empty and occupied holes, was assessed in four study plots in south-western Germany. The aim of this work was to analyse the potential resource conflict between the Starling and the Ring-necked Parakeet, which often breed sympa- 
trically in parks with old trees and are found to use the same type of hole [27-29]. We assumed proportional use of cavities by both bird species among tree size classes and tree species. Furthermore, we assumed an equal distribution of cavities over tree species and a significant number of cases of replacement of Starlings by Ring-necked Parakeets.

\section{MATERIALS AND METHODS}

\section{Study Sites}

Between February and June 2008, four study sites in the Upper Rhine Valley, Germany, were analysed in detail. The study sites were old landscaped parks with tall trees in urban agglomerations: Schlossgarten Schwetzingen, Schlosspark Neckarhausen, Luisenpark Mannheim and Schlosspark Wiesbaden-Biebrich (see Table 1). The region is situated in the temperate zone, with a relatively mild climate. Mean annual temperature in the region (Mannheim) is $10.5^{\circ} \mathrm{C}$, total annual precipitation is $668 \mathrm{~mm}$, elevation $96 \mathrm{~m}$. The maximal distance between the study plots is $77 \mathrm{~km}$ (Schwetzingen-Wiesbaden). Neckarhausen, Schwetzingen, and Mannheim are situated 10-12 km from each other.

\section{Population Development of Ring-Necked Parakeets}

In 1975, the first pair of Ring-necked Parakeets was found breeding in Schlosspark Wiesbaden-Biebrich, with a maximum of 60 breeding pairs in 1996 [29]. In 1974, the first pair bred in Schlosspark Neckarhausen near Heidelberg [19]. From this expanding nucleus the parks in Mannheim and Schwetzingen were colonised by 1993 [19, 30].

\section{Assessment of Tree Holes}

All parks were visited four to ten times and tree holes were systematically searched for in the defoliated trees from February to April using binoculars. Tree holes with an estimated entrance width $<4 \mathrm{~cm}$ were neglected as being too small for the Ring-necked Parakeet or Starling [31, unpubl. data]. Trees with holes $\geq 4 \mathrm{~cm}$ were marked on correspond- ing maps. The occupation of tree holes by Starlings (Feb.Aug.) or Ring-necked Parakeets (Feb.-Jul.), which were the main species breeding in nest holes in the parks, was regularly monitored. The total number of tree holes is not equal to the real number of breeding holes, but serves as an approximation value for the resource "nest hole". Other bird species were just noted when seen by chance. In Schwetzingen, 10 Starling pairs could be observed without knowing their nests. In addition to tree nests there were records of two pairs of Ring-necked Parakeets and three pairs of Starlings breeding in an old ruin in WiesbadenBiebrich.

In order to assess the size of trees with cavities the tree girth was measured at breast height and converted into diameter at breast height (dbh).

\section{Statistical Analysis}

For the comparison of expected with observed values we used $\chi^{2}$-test. A $\chi^{2}$-test was performed in order to find out if cavities were equally distributed over the most common nine tree species, with 'five cavities and more' joined in one column. $\chi^{2}$-test was used to check if the presence of Ringnecked Parakeet and Starling was proportional to the availability of tree holes according to tree size. We used again $\chi^{2}$-test to find out if cavities were equally occupied by both bird species according to tree species. Tree species having cells with less than five breeding pairs of both Starling and Ring-necked Parakeet were discarded.

\section{RESULTS}

In total, 279 trees with cavities were recorded, which belong to 21 genera and 28 species (Table 2). Ring-necked Parakeets used 12 different tree species for breeding, Starlings 13; 12 tree species were not used at all (e.g. Acer campestre and Populus sp.). Both bird species were the most abundant nesters in the examined cavities in the study. Only $2.2 \%$ of trees had holes which were regarded as potential breeding sites, with the largest park in Schwetzingen (72 ha)

Table 1. Background Information on the Study Sites. All Study Sites are Parks Older than 100 Years. Data is also given on the Presence of Ring-Necked Parakeets (RNP) and Starlings (ST), as well as London Planes (Platanus $x$ hispanica) with Cavities. Data of Human Population Around the Parks Serves as an Urbanisation Value of each Area

\begin{tabular}{|c|c|c|c|c|}
\hline Location & Neckarhausen & Schwetzingen & Mannheim & Wiesbaden \\
\hline Founded [year] & 1783 & 1350 & 1892 & 1712 \\
\hline Human population [in $1,000 \mathrm{~s}$ ] & 14.29 & 21.95 & 311.34 & 276.74 \\
\hline Tree hole density/ha & 20.67 & 1.89 & 4.34 & 7.54 \\
\hline Breeding pairs RNP [n] & 15 & 26 & 27 & 32 \\
\hline RNP colonisation [years] & 35 & 15 & 15 & 33 \\
\hline P. $\mathrm{x}$ hispanica trees with holes $[\mathrm{n}]$ & 1 & 2 & 24 & 16 \\
\hline$\%$ RNP broods in $P . \mathrm{x}$ hispanica & 60.00 & 23.08 & 88.89 & 56.67 \\
\hline
\end{tabular}


Table 2. Tree Hole Distribution among the Investigated Tree Species; dbh: Diameter at Breast Height; Only Trees with at Least One Tree Hole $\geq 4 \mathrm{~cm}$ are Listed

\begin{tabular}{|c|c|c|c|c|c|c|}
\hline Tree Species & $\begin{array}{l}\text { Trees } \\
\text { (n) }\end{array}$ & $\begin{array}{l}\text { Cavities } \\
\text { (n) }\end{array}$ & $\begin{array}{c}\text { Starling Cavities } \\
\text { (n) }\end{array}$ & $\begin{array}{l}\text { RNP Cavities } \\
\text { (n) }\end{array}$ & $\begin{array}{l}\text { Cavities Per Tree } \\
\text { (median; range) }\end{array}$ & $\begin{array}{c}\text { Mean } \\
\text { dbh }[\mathrm{m}]\end{array}$ \\
\hline Platanus $\mathrm{x}$ hispanica & 46 & 227 & 3 & 56 & $3 ; 1-36$ & $1.2 \pm 0.34$ \\
\hline Fraxinus excelsior & 27 & 53 & 5 & 6 & $1 ; 1-6$ & $0.69 \pm 0.23$ \\
\hline Quercus robur & 29 & 51 & 17 & 4 & $1 ; 1-5$ & $0.86 \pm 0.27$ \\
\hline Fagus sylvatica & 25 & 49 & 4 & 2 & $1 ; 1-7$ & $0.83 \pm 0.20$ \\
\hline Acer platanoides & 26 & 41 & 5 & 4 & $1 ; 1-4$ & $0.67 \pm 0.15$ \\
\hline Aesculus hippocastanum & 25 & 37 & 6 & 7 & $1 ; 1-4$ & $0.94 \pm 0.23$ \\
\hline Carpinus betulus & 14 & 25 & 1 & 4 & $1 ; 1-5$ & $0.83 \pm 0.23$ \\
\hline Liriodendron tulipifera & 1 & 4 & 2 & 0 & & 0.8 \\
\hline Prunus avium & 2 & 3 & 2 & 0 & $1 ; 1-2$ & $0.7 \pm 0.35$ \\
\hline Salix alba & 1 & 2 & 1 & 0 & & 0.94 \\
\hline Larix decidua & 1 & 1 & 0 & 1 & & 0.7 \\
\hline others & 13 & 18 & & & & \\
\hline Total & 280 & 639 & 69 & 98 & & \\
\hline
\end{tabular}

serving as a representative for all parks based on its high number of trees $(\mathrm{n}=3487)$.

A total of 639 tree holes were found in all the parks studied, out of which 451 (70.6\%) were unoccupied. Ringnecked Parakeets inhabited 98 (15.3\%) tree holes, Starlings $69(10.8 \%)$. In Wiesbaden-Biebrich 14 tree holes were occupied by the Alexandrine Parakeet (Psittacula eupatria), a South Asian species closely related to the Ring-necked Parakeet. The Alexandrine Parakeet has been breeding in Wiesbaden since 1988 [32]. One nest site was occupied by a Green Woodpecker (Picus viridis), three by Jackdaws (Corvus monedula) and two by Honeybees (Apis mellifera).

In this study Starlings took over two breeding sites from Ring-necked Parakeets, with one case vice versa, and Honeybees took over one active Ring-necked Parakeet nest.

\section{Cavity Density Per Tree According to Tree Species}

The executed $\chi^{2}$-test revealed that cavities were not equally distributed among the nine most common tree species $\left(\chi^{2}=70.94 ; \mathrm{df}=32 ; \mathrm{p}<0.001\right)$. Table 2 shows the distribution of tree holes among the examined tree species. Although nearly all common trees $(n \geq 14)$ had a median of 1 cavity, the only exception was the London Plane ( $P$. x hispanica) with a median of 3. A few London Planes had up to nine, and, in an extreme case, 36 holes. Fagus sylvestris had up to seven cavities per tree.

\section{Niche Separation According to Tree Size}

Table 3 shows the distribution of breeding pairs across tree size classes. Neither of both species did behave according to our assumptions of proportional use of cavities among tree size classes. A $\chi^{2}$-test revealed that both bird species select tree diameters that are significantly different from each other $\left(\chi^{2}=54.30 ; \mathrm{df}=8 ; \mathrm{p}<0.001\right)$.

About $60 \%$ of all available nest sites were found in trees with a diameter between 0.4 to $1.2 \mathrm{~m}$. Starlings $(\mathrm{n}=69)$ preferred breeding in medium-sized trees with $0.4-0.8 \mathrm{~m}$ in diameter $(0.76 \pm 0.30 \mathrm{~m})$. Ring-necked Parakeets $(\mathrm{n}=98)$ preferred larger trees $(1.16 \pm 0.36 \mathrm{~m})$. Trees with unoccupied cavities $(n=449)$ had a mean diameter of $1.00 \pm 0.36 \mathrm{~m}$.

\section{Niche Separation According to Tree Species}

A $\chi^{2}$-test for the two bird species according to their use of cavities in the seven most important tree species revealed significant differences in tree species selection $\left(\chi^{2}=77.12\right.$; $\mathrm{df}=12 ; \mathrm{p}<0.001)$.

Table 3 clearly shows that $P$. x hispanica was the most commonly used breeding tree for Ring-necked Parakeet, $57 \%$ of all parakeet nests were found in this tree.

Quercus robur was the most commonly used breeding tree for the Starling (Table 3). An interesting point is that, although there were 42 free tree holes in Acer pseudoplatanus, not even one pair of Ring-necked Parakeet 
Table 3. Proportion of Expected and Observed Nests of the Ring-Necked Parakeet and the Starling among the Tree Size Classes. In the Range of 0.4-0.8 m Diameter of Breast Height (dbh) Starlings Tend to Use More Cavities, whereas Parakeets use Fewer Cavities than Expected by Chance

\begin{tabular}{|c|c|c|c|c|c|}
\hline Tree size category (dbh) & $0-0.4 \mathrm{~m}$ & $0.4-0.8 \mathrm{~m}$ & $0.8-1.2 \mathrm{~m}$ & $1.2-1.6 \mathrm{~m}$ & $1.6-2.0 \mathrm{~m}$ \\
\hline \multicolumn{6}{|c|}{ Ring-necked Parakeet } \\
\hline Proportion nests expected & 0.02 & 0.31 & 0.32 & 0.21 & 0.11 \\
\hline Proportion nests observed & 0.03 & 0.17 & 0.29 & 0.37 & 0.15 \\
\hline $95 \%$ confidence interval & {$[0.28 ; 0.33]$} & {$[0.65 ; 0.73]$} & {$[0.96 ; 1.04]$} & {$[1.29 ; 1.35]$} & {$[1.67 ; 1.76]$} \\
\hline Proportion nests expected & 0.02 & 0.23 & 0.23 & 0.15 & 0.08 \\
\hline Proportion nests observed & 0.03 & 0.41 & 0.23 & 0.03 & 0.02 \\
\hline $95 \%$ confidence interval & {$[0.27 ; 0.35]$} & {$[0.55 ; 0.62]$} & {$[0.90 ; 0.96]$} & {$[1.31 ; 1.35]$} & {$[1.85 ; 1.85]$} \\
\hline
\end{tabular}

used this tree species. Starlings showed a less clear pattern according to tree species. For Starlings $P . \mathrm{x}$ hispanica was used less than expected from the high amount of cavities ( $4 \%$ of broods).

\section{Breeding Pairs Per Tree}

In both examined bird species colonial breeding was found in more than $50 \%$ of pairs, with 'colonial' meaning at least two couples of the same species breeding in the same tree. In Starling $62 \%$ of pairs did not breed alone, whereas in Ring-necked Parakeet colonial breeding was found in 55\% of pairs. A $\chi^{2}$-test conducted could neither reveal significant differences between the bird species nor between single or colonial breeding $\left(\chi^{2}=0.46 ;\right.$ df $\left.=1 ; \mathrm{p}>0.05\right)$. Both bird species are facultative colonial breeders.

The high number of potential breeding sites $(n=36)$ in the single London Plane of Neckarhausen, where Ringnecked Parakeets have bred for the past 35 years, contributed to the largest one-tree-colony known of Ring-necked Parakeet worldwide, composed of nine breeding pairs [33].

The largest Starling colony in this study consisted of five pairs nesting in one $Q$. robur.

\section{DISCUSSION}

The proportion of occupied breeding holes was much higher in this study than in beech forests of Spain, where only $5.5 \%$ of cavities were occupied by birds [34]. The low usage rate of holes in managed forests in Spain was attributed to the lack of good bearing trees with $>45 \mathrm{~cm} \mathrm{dbh}$. Although we do not have complete information on the occupancy of cavities, a large proportion of unoccupied tree holes was detected and this might be suggestive of a surplus of breeding cavities. It should be mentioned that not only the presence, but the quality of cavities contributes to breeding density of hole breeders $[35,36]$. In Wiesbaden we could confirm an increase of cavities since the presence of Ringnecked and Alexandrine Parakeets. Cavity abundance was down to 80-100 by 1990 [32], but increased to 264 in 2008 , although during this period additional 30 former breeding trees were lost due to clearing (D. Franz, pers. comm.). This increase may be attributable to a number of factors like weather, fungus, parasite infections, woodpecker population $[37,38]$, and also the activity by parakeets themselves [39, 40].

Significantly higher numbers of holes in $P . \mathrm{x}$ hispanica than in other park trees, the known excavation behaviour of Ring-necked Parakeets together with the high affinity of Parakeets to this tree may lead to the conclusion that parakeets may contribute to increasing tree hole availability in urban parks. Although Ring-necked Parakeets may not be able to produce tree holes on their own in solid and healthy wood, females in particular are able to enlarge smaller tree holes and tree wounds (e.g. those caused by park management practices) but also excavate new holes in soft-wooded trees, like Salix sp. As a result, tree hole availability has been known to increase with the years [40]. In turn, this may favour the establishment of Stock Doves (Columba oenas), which have increased in numbers especially in established breeding colonies of Ring-necked and Alexandrine Parakeets [40-42]. In this case the Ring-necked Parakeet may even have a beneficial impact on the native avifauna, an aspect often neglected when discussing the impact of non-native species.

Strubbe and Matthysen [21, 43] described an impact of Ring-necked Parakeets on the Nuthatch (Sitta europaea), but not on other tree hole nesting bird species like the Stock Dove, the Great spotted Woodpecker (Dendrocopos major), the Green Woodpecker, the Starling or the Jackdaw. The avoidance of $A$. pseudoplatanus by Ring-necked Parakeets is an unexpected finding as it should be a suitably sized breeding tree for this bird. Such absence of Ring-necked Parakeet in A. pseudoplatanus favoured the Starling.

\section{CONCLUSIONS}

The Starling and the Ring-necked Parakeet were the most abundant hole-nesting species at the examined tree holes. Starlings preferred tree holes in smaller trees than Ringnecked Parakeets. We could not find an apparent replacement of the Starling by the Ring-necked Parakeet despite a 
high sample size. In the whole study, only two Ring-necked Parakeet nests were taken over by Starlings, one Starling nest was taken over by the parrots, supporting a low competition level between these two species. However, we found a niche separation in tree size and tree species which reduced competition between both species considerably. The London Plane $(P . \times$ hispanica) had significantly higher numbers of cavities than any other tree species examined, which may be partly attributable to the parakeets' cavity enlargement behaviour. Based on these findings the listing of the Ring-necked Parakeet as one of the ' 100 worst alien invaders' in Europe [4] does not necessarily reflect the real situation.

\section{ACKNOWLEDGEMENTS}

We thank several persons for supporting this study: Thomas Braunbeck, Rüdiger Becker, Andrea Heger, Gerhard Raab, Eike Schwarz, Christoph Randler, Nina Strychalski, Holger Schäfer, Stefanie Neumann, Detlev Franz, and three anonymous referees. The experiments comply with the current laws of Germany.

\section{REFERENCES}

[1] Cole NC, Jones CG, Harris S. The need for enemy-free space: the impact of an invasive gecko on island endemics. Biol Conserv 2005; 125(4): 467-74.

[2] Cambray JA. The global impact of alien trout species: a review; with reference to their impact in South Africa. Afr J Aqua Sci 2003; 28(1): 61-7.

[3] Smith GC, Henderson IS, Robertson PA. A model of ruddy duck Oxyura jamaicensis eradication for the UK. J Appl Ecol 2005; 42(3): 546-55.

[4] DAISIE. Handbook of Alien species in Europe. In: Drake JA, Ed. Invading nature Springer series in invasion ecology. Dordrecht: Springer Netherlands 2009.

[5] Engeman RM, Groninger NP, Vice DS. A general model for predicting brown tree snake capture rates. Environmetrics 2003; 14(3): 295-305.

[6] Daehler CC, Denslow JS, Ansari S, Kuo H-C. A risk-assessment system for screening out invasive pest plants from Hawaii and other Pacific Islands. Conserv Biol 2004; 18(2): 360-8.

[7] Cowan PE, Tyndale-Biscoe CH. Australian and New Zealand mammal species considered to be pests or problems. Reprod Fertil Dev 1997; 9(1): 27-36.

[8] Wilcove DS, Rothstein D, Dubow J, Phillips A, Losos E. Quantifying threats to imperiled species in the United States. assessing the relative importance of habitat destruction, alien species, pollution, overexploitation, and disease. Bioscience 2008; 48(8): 607-15.

[9] Steiner WWM. Evaluating the cost of saving native Hawaiian birds. Stud Avian Biol 2001; 22: 377-83.

[10] Lederer R. Extinct bird species. 2009 [updated 2009; cited 22.09.2009]; Available from: http://www.ornithology.com/ extinct.html

[11] Kinzelbach R. Die Neozoen. In: Gebhard H, Kinzelbach R, Schmidt-Fischer S, Eds. Gebietsfremde Tierarten - Auswirkungen auf einheimische Arten, Lebensgemeinschaften und Biotope Situationsanalyse. Landsberg: Ecomed 1996.

[12] Geiter O, Homma S, Kinzelbach R. Bestandsaufnahme und Bewertung von Neozoen in Deutschland. UBA-Texte 2002.

[13] Davis MA. Biotic globalization: does competition from introduced species threaten biodiversity? Bioscience 2003; 53(5): 481-9.

[14] Sax DF, Gaines SD. Species invasions and extinction: the future of native biodiversity on islands. Proc Natl Acad Sci USA 2008; 105: 11490-7.

[15] Sax DF, Stachowicz JJ, Brown JH, et al. Ecological and evolutionary insights from species invasions. Trends Ecol Evol 2007; 22(9): 465-71.
[16] Bashkin M, Stohlgren TJ, Otsuki Y, Lee M, Evangelista P, Belnap J. Soil characteristics and plant exotic species invasions in the grand staircase-escalante national monument, Utah, USA. Appl Soil Ecol 2003; 22(1): 67-77.

[17] Bear R, Hill W, Pickering CM. Distribution and diversity of exotic plant species in montane to alpine areas of Kosciuszko National Park. Cunninghamia 2006; 9(4): 559-70.

[18] Hong S-K, Song I-J, Kim H-O, Lee E-K. Landscape pattern and its effect on ecosystem functions in Seoul Metropolitan area: urban ecology on distribution of the naturalized plant species. J Environ Sci 2003; 15(2): 199-204.

[19] Braun M. Population development of the Ring-necked Parakeet (Psittacula krameri) in Europe, Germany, and the Rhine-Neckar Region (Germany: Baden-Württemberg, Rhineland-Palatinate, Hesse), 1962-2008. Vogelwelt 2009; 130: 77-89.

[20] Lever C. Naturalised birds of the world. London: T \& A D Poyser 2005.

[21] Strubbe D, Matthysen E. Experimental evidence for nest-site competition between invasive ring-necked parakeets (Psittacula krameri) and native nuthatches (Sitta europaea). Biol Conserv 2009; 142(8): 1588-94.

[22] Wink M, Dietzen C, Gießing B. Die Vögel des Rheinlandes (Nordrhein). Dossenheim: Romneya Verlag 2005.

[23] PECBMS. The State of Europe's common birds 2008. Prague, Czech Republic: CSO/RSPB 2009.

[24] Smith KW. Has the reduction in nest-site competition from Starlings Sturnus vulgaris been a factor in the recent increase of great spotted woodpecker Dendrocopos major numbers in Britain. Bird Stud 2005; 52: 307-13.

[25] Smith KW. The implications of nest site competition from starlings Sturnus vulgaris and the effect of spring temperatures on the timing and breeding performance of great spotted woodpeckers Dendrocopos major in southern England. Ann Zool Fenn 2006; 43(2): 177-85.

[26] Koenig WD. European Starlings and their effect on native cavitynesting birds. Conserv Biol 2003; 17(4): 1134-40.

[27] Braun M. Alien species in urban habitats: ecology and niche expansion of Ring-necked Parakeets (Psittacula krameri Scopoli, 1769) in Heidelberg, Germany. Marburg Philipps-University 2004.

[28] Ernst U. Afro-asiatische Sittiche in einer mitteleuropäischen Großstadt: Einnischung und Auswirkung auf die Vogelfauna. Cologne University 1995.

[29] Zingel D. Halsbandsittich Psittacula krameri (Scopoli 1769). Avifauna von Hessen: Hessische Gesellschaft für Ornithologie und Naturschutz 1997; pp. 1-6.

[30] Poley D. Halsbandsittiche auch anderswo. Gefiederte Welt 1993; 6: 208-9.

[31] Zeleny L. Starlings versus native cavity-nesting birds. Atlantic Nat 1969; 24: 158-61.

[32] Zingel D. Zum Vorkommen des Halsbandsittichs (Psittacula krameri) im Schloßpark von Wiesbaden-Biebrich. Jahrb Nass Ver Natkd 1990; 112: 7-23.

[33] Shivanarayan N, Babu KS, Ali MH. Breeding biology of Roseringed Parakeets Psittacula krameri at Maruteru. Pavo 1981; 19: 92-6.

[34] Camprodon J, Salvanya J, Soler-Zurita J. The abundance and suitability of tree cavities and their impact on hole-nesting bird populations in beech forests of NE Iberian Peninsula. Acta Ornithol 2008; 43(1): 17-31.

[35] Newton I. Population limitation in birds. London: Academic Press 1994.

[36] Lõhmus A, Remm J. Nest quality limits the number of hole-nesting passerines in their natural cavity-rich habitat. Acta Oecol 2005; 27: 125-8.

[37] Aitken KEH, Martin K. The importance of excavators in holenesting communities: availability and use of natural tree holes in old mixed forests of western Canada. J Ornithol 2007; 148(Suppl 2): S425-S34.

[38] Jackson JA, Jackson BJ. Ecological relationships between fungi and woodpecker cavity sites. Condor 2004; 106(1): 37-49.

[39] Braun M. How does thermal insulation on buildings: as a result of EU climate protection affect the breeding biology of tropical Ringnecked Parakeets (Psittacula krameri) in temperate Central Europe. Ornithol Jahresh Baden-Wurtt 2007; 23(2): 39-56.

[40] Franz D, Krause T. Biologie und Verbreitung des Halsbandsittichs in Deutschland: Teil 1. Papageien 2003; 5: 163-7. 
[41] Krause T. Zur Verbreitung des Halsbandsittichs (Psittacula krameri) im Rheinland im Kontext der gesamten westeuropäischen verbreitung. Bonn Rheinische Friedrich-Wilhelms-Universität 2001.
[42] Kahl-Dunkel A, Werner R. Winter distribution of Ring-necked Parakeet Psittacula krameri in Cologne. Vogelwelt 2002; 123: 1720 .

[43] Strubbe D, Matthysen E. Invasive ring-necked parakeets Psittacula krameri in Belgium: habitat selection and impact on native birds. Ecography 2007; 30: 578-88.

(C) Czajka et al.; Licensee Bentham Open.

This is an open access article licensed under the terms of the Creative Commons Attribution Non-Commercial License (http://creativecommons.org/licenses/by$\mathrm{nc} / 3.0 /$ ), which permits unrestricted, non-commercial use, distribution and reproduction in any medium, provided the work is properly cited. 